\title{
USE OF ART PEDAGOGY IN THE PROCESS OF ADAPTATION OF IMMIGRANT STUDENT TO THE UNIVERSITY
}

\author{
Anna Khilya \\ Vinnytsia Mykhailo Kotsiubynskyi State Pedagogical University, Ukraine \\ Olena Kolosova \\ Vinnytsia Mykhailo Kotsiubynskyi State Pedagogical University, Ukraine \\ Olena Blashkova \\ Vinnytsia Mykhailo Kotsiubynskyi State Pedagogical University, Ukraine \\ Valentyna Hodlevska \\ Vinnytsia Mykhailo Kotsiubynskyi State Pedagogical University, Ukraine
}

\begin{abstract}
The document contains materials on working with first-year students, who have changed their place of residence in connection with the military action in their homeland. The focus of the paper is on the issue of adaptation of immigrant student to the conditions of the university.

We carried out a psychological and pedagogical research using diagnostics of the sociopsychological adaptation of a group of immigrant students (self-acceptance, acceptance of others, emotional comfort, integrity, desire to dominate). We used: Test of Personal Adjustment (C. Rogers, R. Dymond), Eysenck Personality Inventory (H. Eysenck), UCLA Loneliness Scale (D. Russell), Taylor Manifest Anxiety Scale, TMAS (J. Taylor), method of «Three Trees» E. Klessmani to study the characteristics of inter-group and family relations.

The article also analyzed and presented art pedagogy means to help this group of students to overcome difficulties in adapting to the new conditions of life. Namely: elements of a fourcomponent author's program for working with personal orientations and values using the means of art pedagogy in the process of studying basic disciplines
\end{abstract}

Keywords: High school, immigrant students, first year students, adaptation, art pedagogy.

\section{Introduction}

In today's world, migration issues are quite pronounced in all areas of human life. Research on immigration processes covers a wide range of issues. For example, according to the Elsevier research portal, in the scientific community the issues of immigration have been raised in 73,394 publications from 1997 to 2021. A significant number of them relate to Medicine and Dentistry $(32,783)$, Social Sciences $(23,315)$, Psychology $(11,221)$, Agricultural and Biological Sciences (6,430), Economics, Econometrics and Finance (5,673), Arts and 
Khilya et al., 2021. Use of Art Pedagogy in The Process of Adaptation of Immigrant Student to the University

Humanities (5,614), Environmental Science (4,725), Immunology and Microbiology $(4,465)$, Business, Management and Accounting $(4,394)$ and Nursing and Health Professions (4,067). But for our research, the most important are Social Sciences $(23,315)$, Psychology $(11,221)$ and partially Arts and Humanities. So, by refining the sample to «immigrant students» we found a total of 23,438 results, of which only 1,841 results are in the public access or open archives.

Among the issues that have been raised internationally and are more relevant to our research, we can mention the following:

- medical issues for example access to healthcare;

- $\quad$ social and management / state issues like documentation, culture and financial literacy;

- $\quad$ psychosocial and pedagogical aspects.

For instance, among the latter we were most interested to learn about the issues considered by academics and experts in terms of psychology and pedagogy: «The Role of Intercultural Pedagogy in the Integration of Immigrant Students in Europe» (Sani, 2014), «Interculturality and Social Bonds Formation: A Case Study on Immigrant and Native Preadolescents in Italy» (Contini, 2014), «The Curricular and Social Integration of Immigrant Students: Parallel Roads» (Bocero, Fernández Larragueta, Fernández Sierra, 2014), «The Academic Inclusion of Immigrant Students» (Sani, 2015), «Influence of Immigrant Students' Communication Skills on their Teaching and Learning Process» (Martín-Pastor, González-Gil, Río, Robaina, \& Castro, 2013) and others.

Additionally, it is worth noting that migration issues in Ukraine correlate with the start of the anti-terrorist operation in the non-government-controlled territories, which started in 2014. It was the last eight years that the issue of displaced persons became quite critical and required finding solutions for the social, cultural adaptation and educational inclusion of students from the internally displaced population. Currently, at Vinnytsia Mykhailo Kotsiubynskyi State Pedagogical University, the annual enrolment of this category of students' remains stable at least 20-35 persons. That is what accompanied the beginning of our research in terms of socio-psychological adaptation of first-year students from among internally displaced persons. This in turn includes questions of the level of personal adaptability to life in society, the ability to meet the requirements of society and at the same time not to forget about their own needs, motives and interests.

The aim of research - to characterize the main components influencing the adaptation of migrant students to university conditions and define systematic art pedagogical work for quality support of students' personality and professional development based on the proposed components. 
Based on what we have identified the following objectives for our survey:

- $\quad$ to analyze psychological and pedagogical aspects of the process of migrant students' adaptation in the first year of higher education;

- to select the most relevant art pedagogical tools for the process of student adaptation and establish «safe» ways of integrating art-therapy techniques into the higher education process.

\section{Methodology of Research}

In order to study the level of adaptation of the migrant students to the conditions of the higher education institution, we conducted a psycho-pedagogical research, during which we diagnosed 40 students of the Faculty of Preschool, Primary Education and Art named after Valentina Voloshina of the Vinnitsa State University named after Mykhailo Kotsyubinskiy. The Research was realized in September-October 2020 (Sarancha, Khilya, 2020). We formed two groups of research participants. The basic features of them are described in Table 1.

Table 1 The Main Characteristics of the Research Groups

\begin{tabular}{|l|c|l|l|l|}
\hline \multicolumn{1}{|c|}{ Participants } & Number & \multicolumn{1}{c|}{ Gender } & Age & Course \\
\hline Resident students & 20 & Female & $17-18$ & First \\
\hline Immigrant students & 20 & Female & $17-18$ & First \\
\hline
\end{tabular}

Our research consisted of several stages.

At the first stage, we used the following diagnostic techniques in order to explore the question of the adaptation of immigrant students:

- $\quad$ adjusted Socio-psychological Adaptation Scale (SPA scale) developed by C. Rogers and R. Rogers and R. Diamond, consisting of 101 items, of which 37 items correspond to the criteria of personal sociopsychological adaptability, the next 37 items correspond to the criteria of disadaptation (rejection of self and others, the presence of «protective barriers», the seeming unable to «solve» the problems, rigidity inflexibility of mental processes), 9 statements make the control scale («Lie scale»), the rest are neutral (Lemak, Petryshche, 2012), and also the subsequent establishment of statistical validity according to the tStudent criteria between the indicators of socio-psychological adaptability among immigrant students and residents of the territory;

- $\quad$ adapted Hans Eysenck personality questionnaire (EPI) was used to identify students' temperament type, taking into account introversion and extraversion of their personality, and emotional resilience. Students 
had to answer 57 question which aimed to identify their usual way of behavior (Kyrsheva, Riabchykova, 1995);

- $\quad$ to survey the level of students' perception of their loneliness we used an adaptation of D. Russell and M. Ferguson's method (Podoliak, Hlavnyk, 2006), which allowed us to identify the state of loneliness and possible correlation of this state with anxiousness, social exclusion, depression and ennui (Raihorodskyi, 2001).

At the second stage, we used E. Klessmann's «Three Trees method» (Klessmann, 1990; Klessmann, Eibach, 1993) to study characteristics of intergroup, family relationships, followed by interviews with participants in a psycho-pedagogical survey (Shapar, 2006).

At the third stage, we developed a program of art-therapy sessions that was based upon the adapted author's art-therapy method «The Journey of the Country of Lydia» (Khilya, 2017), and also uses training forms of work, taking into account their sequence, reflexive and other exercises (Demchenko, Koval, Vatso, Lymar, \& Turchyna, 2020).

\section{Results of the Research}

\section{Results of the first stage of the psychological-pedagogical survey}

The first-year students had to correlate the statements contained in the questionnaire about a personality, about his/her way of life, experiences, mentions, habits, and behavior style with their lifestyle; rate the statements, by choosing one of the seven options numbered from «0» to «6»: from «does not apply to me» to «this is exactly about me». We calculated the number of scores the examined students got according to the key on the following scales: adaptability - unsuitability; lie scale; acceptance - non-acceptance of oneself; acceptance - non-acceptance of others; emotional comfort - discomfort; internal external control; domination - controllability; escapism (escape from problems). A survey of the level of adaptability of both groups is illustrated in Figure 1.

The analysis of the research results allows us to establish that the indicators for all scales are in the range from $54 \%$ to $73 \%$. The scale «self-acceptance» (71\%) is the most pronounced among the migrant students and «emotional comfort» - 73\%, which indicates that the students have an internal calm. In addition, such qualities as «adaptation», «acceptance of others», «integrity», are at an average level. The least expressed scale in the two groups is «the desire for dominance» (54\%). 


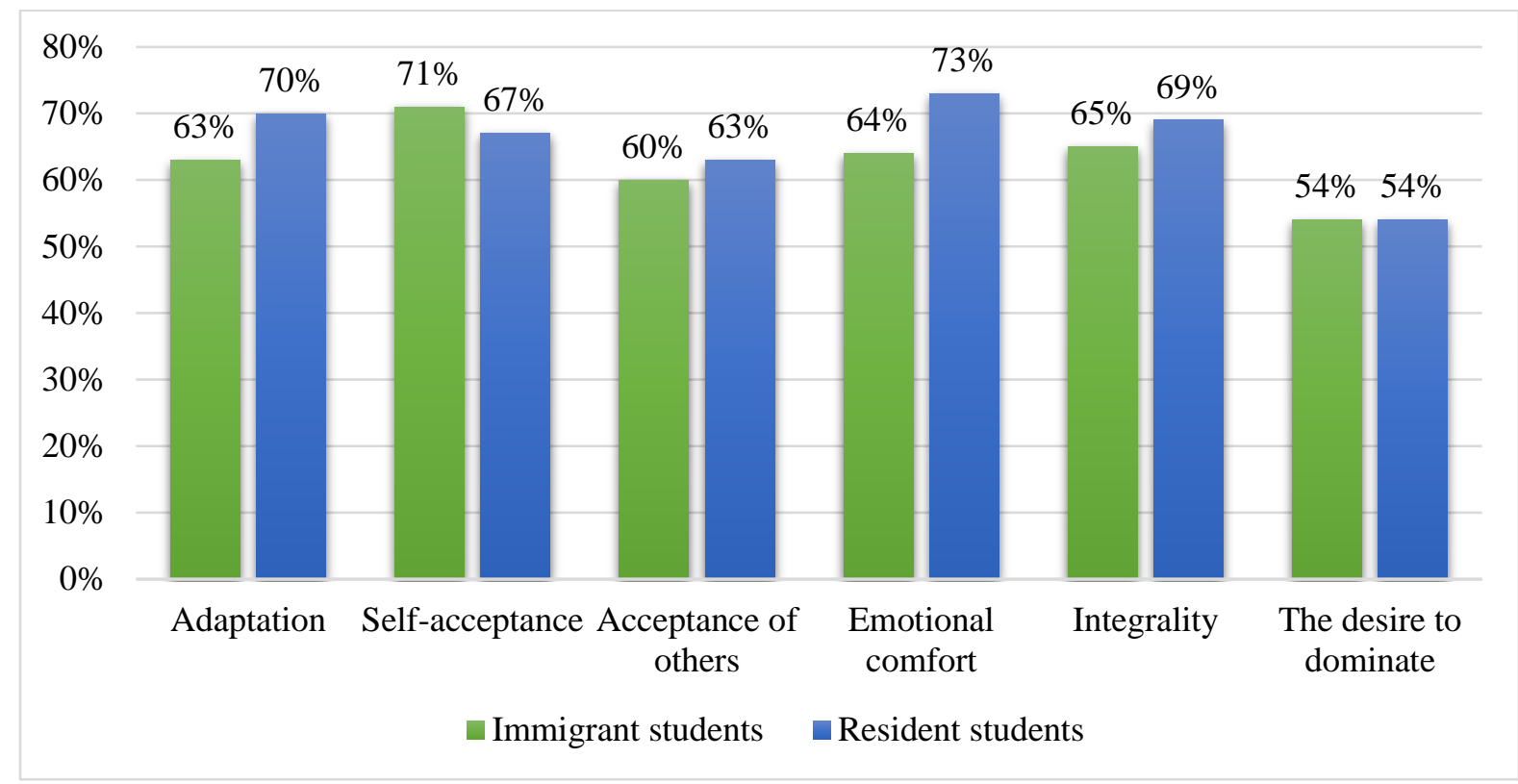

Figure 1 Results of the Survey of Immigrant and Resident Students

As a result of the analysis of the research data, it was found that the students of both groups had high and normal adaptability according to the integral indicator «adaptation». On the scale of «emotional comfort», the indicators were located at a high level, and the difference was 9\%. The resident students have a higher level of emotional comfort compared to the migrant students.

On the self-acceptance scale, the percentage difference is $4 \%$ (the immigrant students are higher than the resident students). In two groups, the level of «selfacceptance» is relatively high. On the scale of "acceptance of others» the difference in percentage was 3\% (resident students have this scale higher in comparison to immigrant students). The indicators are located at the average level closer to the high level.

The percentage difference on the «integrity» scale was $4 \%$ (resident students have a higher percentage difference than immigrant students). The indicators are located at the average level closer to the high level.

On the scale of «desire for dominance», we did not detect any difference in the percentages. The indicators are located at the average level. Therefore, the study of socio-psychological adaptability according to the methodology: C. Rogers and R. Diamond in the two groups of subjects showed that the migrant students have a lower level of socio-psychological adaptability compared to the resident students.

The next stage of the study was to use the EPI to determine the type of temperament, the emotional background and the introversion/extraversion of the student's personality. So, among the respondents, only 11 students scored 12 or more on the first scale and are extroverts, of them 7 resident students and 4 
migrant students. They are characterized by an outward orientation, flexibility of behavior, communicative and social adapting, they are direct, active, open in their emotional expressions, and impulsive. 29 students scored less than 12 and are introverts who are most interested in their own inner world. They are unsociable, withdrawn, have difficulties in social adaptation and are often socially passive. The results of the second scale diagnostics revealed that 24 students are emotionally stable. Among them, 9 students are immigrants. Another part - 16 students were emotionally unstable.

These results of the survey analysis allow us to suggest difficulties that may arise in working with students to improve their level of socio-psychological adaptation. Because introverts are not inclined to share their inner feelings, live their problems within themselves are less communicative, and emotional instability leads to deviant behaviors'.

The follow-up study was based on the adapted methodology of D. Russell and M. Ferguson and allowed us to determine the indicators of feelings of loneliness among resident students correspond to a low level and among migrant students to an average level. Thus, resident students were characterized by feelings of social anxiety, higher levels of shyness, higher levels of isolation and lower levels of self-esteem. They were also less friendly towards others, as they assessed themselves and others more negatively and, are proponents of short-lived social interactions.

We confirmed the results of this survey in the process of using the method of measuring the level of anxiety on the J. Taylor scale. The analysis of the answers to the questionnaire allowed us to establish that 5 migrants and 3 resident students have a high level of anxiety. They are characterized by low self-esteem and high emotionality. They are not communicative, do not express their opinions or feelings, and are very receptive. The average level of anxiety, tending to high, was diagnosed in 10 migrants and 9 resident students. Although they are calm, sociable and have moderate self-esteem, they may experience some unreasonable anxiety. Average, aspiring to low anxiety levels are found in 5 migrants and 6 students residing in the territory. This group of students is characterized by the ability to defend their point of view, has an independent outlook and high selfesteem, and is receptive to criticism. Anxiety visits these people infrequently and only after the fact. Low level of anxiety was diagnosed in 2 resident students who were lazy and irresponsible, but when it came to personal interests, they got mobilized and achieved the desired result. The feeling of fear or anxiety arises only in a typical situation. It is also worth noting that during the research, a very high level of anxiety was not detected among the respondents.

Information collected as a result was used in choosing art-therapy as the most effective adaptation technique. Because it is art-therapy that can relieve anxiety, soften emotional «outbursts» and prevent «alienation» of the student group 
participants. As it is directed creativity with a therapeutic orientation that improves both self-determination, self-awareness of the individual and the group.

\section{Results of the second phase of the psycho-pedagogical survey}

Family has a significant influence on the development of sociopsychological adaptation. In order to identify the peculiarities of intra-familial relations, we used the «Three Trees» method by E. Klessmani. We suggested that the students draw three trees on one horizontally arranged list, and then compare them with the members of the student's family (Figure 2). After completing the work, we had an individual interview with the students for the following questions:

- What are the names of the trees?

- Which one do you like best?

- Why do you like it best?

- Which tree is younger (older) than the others?

- Which one do you think is the cutest?

- Which one is ugly and why?

- Why is the tree crooked?

- etc.

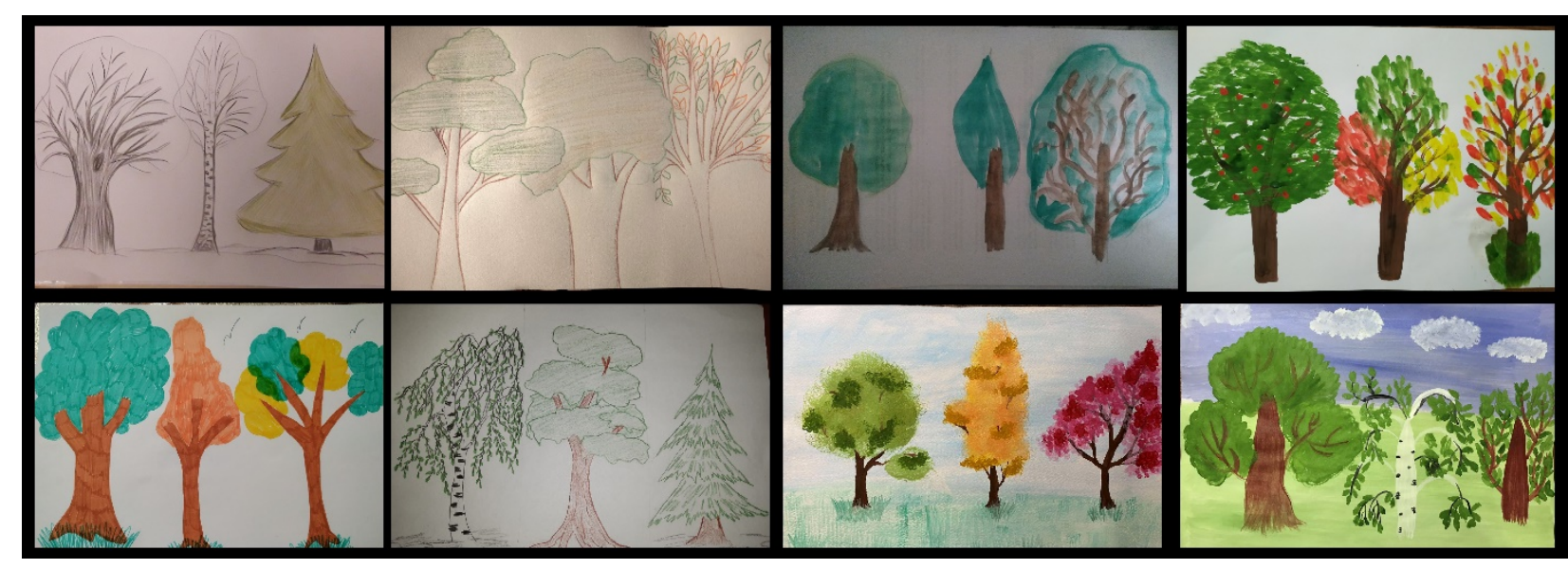

Figure 2 Some Examples of Student Work on the «Three Trees» Methodology

Then we suggested that the students imagine themselves as a gardener and take care of the trees («You are the gardener, what will you do with each tree?»). The final step was to ask the test taker to compare each tree to a family member.

During the interpretation, we considered: whether the drawing was made with all the details (location and size of trees, details, colors); answers to the surveyor's questions; association of trees with relatives; the student's suggested actions with the plants; the test taker's behavior, emotional and bodily reactions. 
Interpretation of the drawings made it possible to establish that the largest and most visible tree the students drew was the one they associated with the main person in the family - the father. As a rule, they put this tree in the first place, as he has all the responsibility on his shoulders.

In the center, the students portrayed the most important character to them their mother or themselves. It could be argued that the portrayal of the self between the two parents is indicative of the role of the «guide», communication between the adults is only through the daughter, and between themselves is kept to a minimum.

Most of the plants were drawn on a common ground - a good indicator that shows the stability and strength of the family relationship. Trees that are depicted on divided ground are more likely to have different interests, views, which disrupts their relationship. Trees that lack the grounded terrain, the roots, are indicative of separation, detachment from the home area. Such drawings were characteristic of the settler students. Also, some students placed trees close to each other or at a considerable distance, which signaled the importance of relationships with people close to them.

As the size of the object shows the importance of this or that family member in the student's life, we can state mostly equal treatment of loved ones. It is worth noting the curvature of trunks in the students' drawings, the curvature of branches, the presence of a hollow, which indicate injury, illness, and disadvantage to parents or themselves. Trees with fruit, and there were a few of these, indicate loved ones who "serve the good», in most cases these were mothers. We also analyzed students' color preferences, taking into account that each spectrum has both positive and negative indicators, as well as color saturation of the drawing. Which allowed us to establish the emotional state of the students, their involvement in family relationships.

When students chose the role of gardener, seeking to change the condition of the trees in some way, this symbolized a desire to make certain changes in the relationship with the family, as well as a possible lack of communication with close relatives or people significant in the subject's life.

Therefore, we found that most students have a close emotional bond with their parents, the dominant position in the family - is held by their fathers and the closest and most important person for them is their mother. There are also families in which there is disconnection, psychological trauma triggered by forced relocation from the home area, which has had a negative impact on intra-family relationships; and for the level of socio-psychological adaptation of first-year students. In our opinion, it is important that the students are willing to rectify the situation and influence their family relationships. 


\section{Discussion}

The third stage of our psycho-pedagogical survey continues. Following the analysis of the survey data, we found that the level of socio-psychological adaptation among resettlement students is lower than among resident students. As a result, teachers developed a number of art-therapeutic inclusions based on the author's method «Journey by the Country of Lydia». These materials were used during the mentoring hour to increase the level of adaptation and formation of positive social connections in the process of creative activity followed by a group discussion without focusing on personal issues of internal self-perception and experiences. It is also important that the students had the opportunity to get acquainted with the proposed methodology as future professionals to work with children and remain in the «safe zone» of their personal comfort.

The main topics of the art pedagogical training sessions, for example, should include the following areas of work:

- Introductory session. Introducing the country of «Lydia» and its inhabitants, which will establish a microclimate and create a new «first contact» between the students, facilitator (in our case, the supervisor). At this stage, we can use group or individual work of the students on a creative task. The choice of technology depends on the group, but we most often use different types of drawing;

- $\quad$ Main session, which can include several activities and training activities on topics «One place in the country of Man»; «Society and I»; «About social roles»; "Where do I live with my family?»; «All of us are different. Exercises for revision and mutual cooperation»; «Our joint laws for the country of Man»; «The Stone of Choice»; «Professions in Our Lives»; «The Place of Your Dreams» and other practical activities. These activities allow you to form a light and creative environment to support the personality of each student, teach them to understand themselves and their emotions, to accept the emotions of others and develop a good, comfortable relationship, even in a stressful situation.

- $\quad$ Summary session. A wish list, which can combine group and individual work on the wishes of all groups that will be remembered by each participant, or it can be the start for the next session about technologies for achieving success and the goals set.

Procedures and the internal content of the training exercises should be flexible enough to respond in a timely manner to the internal state situations of the immigrant students and the communication processes in the group. And arttherapy techniques can be adapted to the students' preferences and include any kind of art - from drawing to sculpting or knitting. 
Khilya et al., 2021. Use of Art Pedagogy in The Process of Adaptation of Immigrant Student to the University

\section{Conclusions}

Therefore, in accordance with the tasks of our research we have considered the issues of adaptation of students of immigrants as a complex problem. Covering both the information field and the actual components of the psychological concept of adaptation to the conditions of the university, such as self-acceptance, acceptance of others, emotional comfort, integrality, the desire for dominance and temperament type, and as important components - the level of anxiety, subjective sense of loneliness, extraversion and emotional stability. All these indicators together with the features of the family environment and communication in society allow us to determine the presence of a stressful situation in connection with a change of residence, a change of social role and possible problems of selfrealization and socialization of migrant students.

Based on such a complex diagnosis, teachers and specialists of higher education can use the unobtrusive, comfortable means of art-pedagogy to relieve psychological stress, establish communication and interaction with others in a positive way. So, it is consecutive and systematic use of specially developed methods of art-pedagogy will allow the migrant students «softer» to enter a new society and a new role - a first year student of the university.

\section{References}

Bocero, G. L. S., Larragueta, S. F., \& Sierra, J. F. (2014). The curricular and social integration of immigrant students: parallel roads. Procedia-Social and Behavioral Sciences, 116, 1101-1105. DOI:10.1016/j.sbspro.2014.01.352.

Contini, R. M. (2014). Interculturality and social bonds formation: A case study on immigrant and native preadolescents in Italy. Procedia-Social and Behavioral Sciences, 149, 233241. DOI:10.1016/j.sbspro.2014.08.223

Demchenko, O., Koval, T., Vatso, M., Lymar, Y., \& Turchyna, I. (2020). Development of a Reflective Component of Future Teacher's Readiness to Work with Gifted Children During Training. In SOCIETY. INTEGRATION. EDUCATION. In Proceedings of the International Scientific Conference, Volume I, Vol. 119, p. 119-132. [Datafile]. Retrieved from https://core.ac.uk/download/pdf/327119489.pdf

Khilya, A.V. (2017). Journey by the Country of «Lydia»: Vykhovannia tsinnisnoho stavlennia do otochuiuchoho sotsiumu u ditei (z simei, yaki opynylys u skladnykh zhyttievykh obstavynakh, zokrema - ditei z funktsionalnymy obmezhenniamy) zasobamy art-terapii. Chastyna II. A.V.Khilia, za red I. Sarancha, O. Derkach. Vinnitsia. 2017. 44.

Klessmann, E. (1990). Das Katathymes Bilderleben als Spiegel gesturter Familienbeziehungen bei Kindern und Jugendlichen. In Leuner, H.: Katathymes Bilderleben - Ergebnisse in Theorie und Praxis, 3. Aufl. Huber. Bern 1990.

Klessmann, E., Eibach H. (1993). Wo die Seele wohnt : das imaginдre Haus als Spiegel menschlicher Erfahrungen und Entwicklungen, Huber, Bern, Gцttingen, Toronto 1. Aufl. 1993. 
Kyrsheva, N.V., Riabchykova, N.V. (1995). Psykholohyia lychnosty: testbl, oprosnyky, metodyky. Moskva : Helikon, 236.

Lemak, M.V., Petryshche, V.Iu. (2012). Psykholohu dlia roboty. Diahnostychni metodyky : zbirnyk [Tekst]. Uzhhorod : Vydavnytstvo Oleksandry Harkushi, 616.

Martín-Pastor, E., González-Gil, F., Río, C. J., Robaina, N. F., \& Castro, R. P. (2013). Influence of immigrant students' communication skills on their teaching and learning process. Procedia-Social and Behavioral Sciences, 93, 789-793. DOI:10.1016/ j.sbspro.2013.09.280.

Podoliak, L.H., Hlavnyk, O.P. (2006). Osnovy pedahohichnoi psykholohii (psykholohiia vykhovannia). Navchalnyi posibnyk. Kiev : Hlavnyk. 2006. 112.

Raihorodskyi, D. Ia. (2001). Praktycheskaia psykhodyahnostyka. Metodyky y testi. Samara: yzdatelskyi dom «BAKhRAKh M», $672 \mathrm{p}$.

Sani, S. (2014). The role of intercultural Pedagogy in the integration of immigrant students in Europe. Procedia-Social and Behavioral Sciences, 122, 484-490. DOI:10.1016/j.sbspro.2014.01.1379.

Sani, S. (2015). The academic inclusion of immigrant students. Procedia-Social and Behavioral Sciences, 197, 1152-1155. DOI:10.1016/j.sbspro.2015.07.370.

Sarancha, I., Khilya, A. (2020). Socio-educational activity of students in the framework of social projects. Ukr. socium, 2020, 4(75), 125-135. DOI:10.15407/socium2020.04.125.

Shapar, V. B. (2006). Psykhodyahnostyka otnoshenyi mezhdu rodyteliamy y detmy. Yzdatelstvo: Rostov na Donu: Fenyks, 432. 